\title{
The Nutritive Value of Nylotic Fish
}

\author{
Samia H Abdelrahman ${ }^{1 *}$, AM Sara' ${ }^{2}$, Salwa ME Khojali², HA Elrayah' ${ }^{2}$ and Tarig HA Bilal ${ }^{2}$ \\ ${ }^{1}$ Animal Resources Research Corporation, Veterinary Research Institute, Sudan
}

${ }^{2}$ Sharg Alneel College, School of Medical Laboratories, Khartoum, North Sudan

Received: August 21, 2017; Published: September 07, 2017

*Corresponding author: Samia H Abdelrahman, Animal Resources Research Corporation, Veterinary Research Institute, P.0. Box 8067, Alamarat, Khartoum, Sudan, Email: samiah11@gmail.com

\begin{abstract}
Fishing is one of the oldest occupations in Sudan. Fishing has assumed much importance in view of the rapidly growing population and depleting land resources. Fish confirm a very nutritional part of man's diet. It is rich in protein. It contains a good selection of minerals and vitamins. This study was conducted in estimating these biochemical components. 300 samples of Nylotic fish were tested. It was found that the levels of sodium is $72-85 \mathrm{mg} / 100 \mathrm{~g}$, potassium $279-380$, calcium 79-210, magnesium 38-95, iron 1.55-3.4, zinc 0.96-1.34, copper 0.20-1.4. The vitamins tested were found to be 70-350(I.U) for vitamin A and 1.5-3.6 $\mu \mathrm{g} / \mathrm{g}$ for vitamin C. The protein was found to be $15-20 \%$ whereas the fat $20-30 \%$.
\end{abstract}

Keywords: Fish; Minerals; Vitamins; Protein

\section{Introduction}

Sudan's huge fishing potentialities and fish resources are represented by the 800 kilometers coastline on the Red Sea and about 42 billion square meters of fresh water stretched from lakes and rivers, the most important of which are the river Nile and its tributaries. That collectively harbors an estimated fish potential of 23700 tons annually and produces 17000 tons annually. The fish inventory reservoirs at Sennar, Roseiris, and Jebel Awlia Dam in addition to the Nubian lake at Wadi Halfa, account for hundreds of thousand tons of fish in fresh and marine waters FAO [1].

The inland fisheries are mainly on the River Nile and its tributaries, contributing over $90 \%$ of the estimated production potential of the country. The sudd swamps in the south and the manmade lakes on the White Nile (Gebel Awlia Reservoir), the Blue Nile Reservoir Sennar Reservoir and Atbara River (Khashm Elgirba Reservoir) are the major fishing localities with respect to fish resource magnitude and exploitation thrust. People in the developing countries are generally much more dependent on fish as a part of their daily diets than people living in the developed world. It may be used fresh, frozen, canned, cured salted, dried or smoked. Fish meal and fish flour are two products of the fishing industry used for the dairy animals and poultry feeds and so add to the world's supply of protein rich food. Fish is an important and highly desirable food for people suffering from protein, energy and malnutrition which is a leading cause of infant mortality in the developing world. It could be good source against endemic goiter caused by lack of dietary iron and iodine. Each 100 grams of lean or white fish contains less than $1 \%$ of fat, about $18 \%$ of protein and an energy value range of 50-80 k.cal. Oily fish contains $8-15 \%$ of fat and so has a higher energy value (80-160kal/100g) Mohamed [2].

\section{Economic Importance}

Fish is marketed and consumed fresh (63\%), sun dried (28\%) or wet salted $(9 \%)$. The fresh fish is transported from distant fishing grounds to consumption areas in the capital, Khartoum and other towns, either chilled or refrigerated. Sun dried fish is mostly marketed in rain fed and mechanized agricultural schemes. Wetsalted fish mainly (hydrocyon, spp, Atestes spp and mugil spp) is intended for both domestic consumption and export. Shells of the mother of pearl oyster are exported to some European countries. Other molluse shells are harvested and sold locally as a source of calcium for poultry feed or as souvenirs. Shrimps and prawns are sold locally as a highly valued delicacy food, particularly in the first class hotels FAO [3].

Fishing is one of the oldest occupations of man. Fishing has assumed much importance in view of the growing population. Fish also provides protein rich food and is also a big source of vitamin A, B, and D. The needs for knowledge of normal values of nutrient content of fish is important

\section{Material and Methods}

300 samples of Nylotic fish weighing $1.4 \pm 0.4 \mathrm{~kg}$ were collected. Blood was collected from the ductus cuvieri as described by Lied et al. (1975) with the following modification: instead of pulling 
the piston by hand, a needle attached to held in the drawn-out position; blood was regulated to avoid vessel collapse by adjusting the vacuum. Approximately $10 \mathrm{ml}$ blood was withdrawn from each fish and the serum was separated and kept at $4 \mathrm{oC}$ for analysis. The Potassium and Sodium and phosphorous content were determined according to the method described by AOAC [4], using flame photometer (Corning 400).

Analysis of phosphorus was performed using UNICAM 8625 UV/ Vis spectrometer. Calcium was determined by Atomic Absorption Spectrophotometer. The same method was used for determination of Zinc, Copper and ferrous with different standards. Protein and fat was determined according to the method of Petterson et al. [5]. Fat was determined by Gerber's method and kildahel methods were used to determine the nitrogen content. A nitrogen conversion factor of 6.38 was used for calculation of protein content of fish samples.

\section{Results and Discussion}

Table 1: Minerals content of Fish samples.

\begin{tabular}{|c|c|}
\hline Parameter & Concentration \\
\hline sodium & $72-85 \mathrm{mg} / 100 \mathrm{~g}$ \\
\hline Potassium & $279-380 \quad 21 \%$ \\
\hline Magnesium & $38-95$ \\
\hline Calcium & 57-757 \\
\hline Iron & $1.55-3.4 \quad 3 \%$ \\
\hline Zinc & $0.96-1.34 \quad 6 \%$ \\
\hline Copper & $0.20-1.4 \quad 4 \%$ \\
\hline Phosphorous & $572 \mathrm{mg}$ \\
\hline Manganese & $0.02 \mathrm{mg} \quad 1 \%$ \\
\hline
\end{tabular}

The present paper reports on normal values of healthy samples of fishes. Minerals as well as proximate analysis of protein and fats were analyzed (Table 1). It was found that the levels of sodium is 72-85mg/100 g, potassium 279-380, calcium 79-210, magnesium 38-95, iron 1.55-3.4, zinc 0.96-1.34, copper 0.20-1.4. The vitamins tested were found to be 70-350(I.U) for vitamin A and 1.5-3.6 $\mu \mathrm{g} / \mathrm{g}$ for vitamin C. The protein was found to be $15-20 \%$ whereas the fat 20-30\% (Tables $2 \& 3$ ). From the results above it was proved that fish is a good source of minerals and contains high level of protein which can be an alternative food for many consumers that cannot depend on animal protein. People in the developing countries are generally much more dependent on fish as a part of their daily diets than people living in the developed world. The need for knowledge of normal values of theses parameters is stressed by several authors Sandnes et al. [6] who studied the blood parameters as well as the haematology of the Atlantic Salmon Hamid et al. [7]. Who approved that hematological analysis can provide valuable knowledge for monitoring the health and conditions of both wild and cultured fishes. He measured and compared blood parameters and studied their correlations for Caspian salmon Salmo trutta caspius.

Table 2: Proximate analysis.

\begin{tabular}{|c|c|}
\hline Protein content & $15-20 \%$ \\
\hline The total fat content & $20-30 \%$. \\
\hline Saturated fat & $6-10 \%$ \\
\hline
\end{tabular}

Table 3: Vitamin contents of Fish samples.

\begin{tabular}{|c|c|}
\hline Vitamins & Percentage \\
\hline Vitamin A & $897 \mathrm{IU} \quad 18 \%$ \\
\hline Vitamin C & $7.9 \mathrm{mg} \quad 13 \%$ \\
\hline Vitamin E & $2.4 \mathrm{mg} \quad 12 \%$ \\
\hline Thiamin & $0.1 \mathrm{mg} \quad 7 \%$ \\
\hline Riboflavin & $0.2 \mathrm{mg}$ \\
\hline Vitamin B6 & $0.8 \mathrm{mg} \quad 40 \%$ \\
\hline
\end{tabular}

\section{References}

1. FAO (2006) World Review of Fisheries and Aquaculture, Annual report part 1, FAO, Rome, Italy.

2. Mohamed Y (1999) Production and marketing of fish in Blue and White Niles. M.Sc. Thesis, University of Khartoum, Sudan.

3. FAO (2002) Information on Fisheries Management in Republic of the Sudan, FAO, Rome.

4. AOAC (1981) Official methods of analysis Published by the Association of official analytical scientists. Inc. Arlington, 70(4): 468.

5. Petterson DS, Harris DJ, Rayner CJ, Blakeney AB, Choct M (1999) Methods for the analysis of premium livestock grains. Australian Journal of Agricultural Research 50(5): 775-787.

6. Sandnes K, Lie QU, Waagbo RI (1988) Normal range of some blood chemistry parameters in adult farmed Atlantic salmon Salmo Salar. J Fish Biology 32(1): 129-136.

7. Hamid RJ, Shahrbanoo O, Mohammad RG (2008) Hematological characteristics and correlations of diploid and triploid Caspian salmon Salmo trutta caspius in juvenile stage. Journal of Cell and Animal Biology 2(12): 195-198.

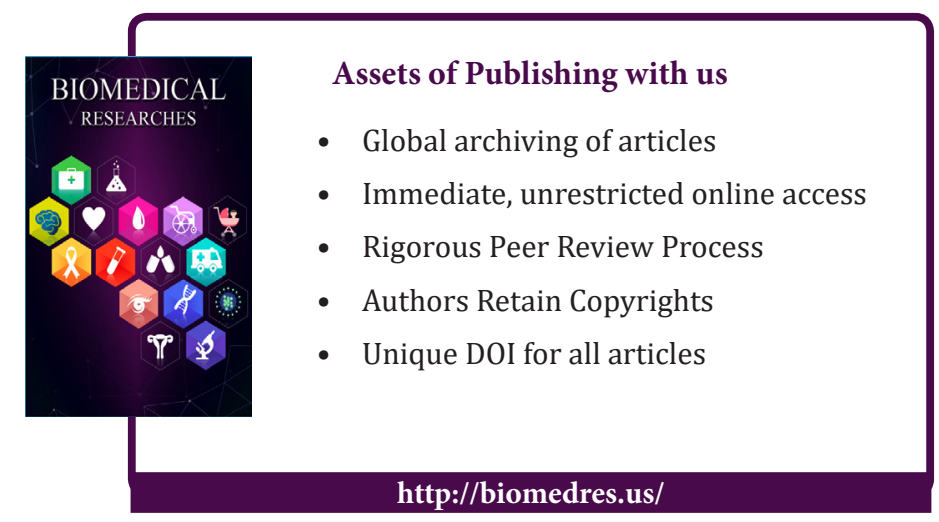

